Article

\title{
Municipal Responses to 'Illegality': Urban Sanctuary across National Contexts
}

\author{
Harald Bauder ${ }^{1, *}$ and Dayana A. Gonzalez ${ }^{2}$ \\ ${ }^{1}$ Department of Geography and Environmental Studies, Ryerson University, Toronto, ON M5B2K3, Canada; \\ E-Mail: hbauder@ryerson.ca \\ ${ }^{2}$ Graduate Program in Immigration and Settlement Studies, Ryerson University, Toronto, ON M5B2K3, Canada; E-Mail: \\ dgonzalez@ryerson.ca \\ * Corresponding author
}

Submitted: 19 November 2017 | Accepted: 6 January 2018 | Published: 29 March 2018

\begin{abstract}
Cities often seek to mitigate the highly precarious situation of Illegalized (or undocumented) migrants. In this context, "sanctuary cites" are an innovative urban response to exclusionary national policies. In this article, we expand the geographical scope of sanctuary policies and practices beyond Canada, the USA, and the UK, where the policies and practices are well-known. In particular, we explore corresponding urban initiatives in Chile, Germany, and Spain. We find that varying kinds of urban-sanctuary policies and practices permit illegalized migrants to cope with their situations in particular national contexts. However, different labels, such as "city of refuge," "commune of reception," or "solidarity city" are used to describe such initiatives. While national, historical, and geopolitical contexts distinctly shape local efforts to accommodate illegalized migrants, recognizing similarities across national contexts is important to develop globally-coordinated and internationally-inspired responses at the urban scale.
\end{abstract}

\section{Keywords}

migrants; municipalities; refuge; sanctuary cities; scale; solidarity cities

\section{Issue}

This article is part of the issue "The Transformative Forces of Migration: Refugees and the Re-Configuration of Migration Societies", edited by Ulrike Hamann and Gökçe Yurdakul (Humboldt University of Berlin, Germany).

(C) 2018 by the authors; licensee Cogitatio (Lisbon, Portugal). This article is licensed under a Creative Commons Attribution 4.0 International License (CC BY).

\section{Introduction}

In light of the Trump administration's threats to cut funding to sanctuary cities, the mayors of Chicago, Los Angeles, New York, and many other US cities have reaffirmed their commitment to accommodating migrants who do not possess full federal status (Robbins, 2017). In Canada, Toronto, Hamilton, London (Ontario), and Montreal, have also declared themselves sanctuary cities (Montpetit, 2017). In the UK, cities of sanctuary, such as Sheffield, are welcoming refugees.

These cities respond to the disjuncture between exclusionary national migration and residency policies, and the need to be inclusive at the local scale. They address the problem that national governments issue visas, permits, or permanent residency documents to some migrants but deny these documents to others already living in the country, effectively "illegalizing" persons who are de-facto residents of the cities (Bauder, 2014). This problem also arises when failed refugee and asylum claimants resist deportation and stay in the country, and when migrants cross the border irregularly. Sanctuary cities implement municipal policies and practices to accommodate these inhabitants.

Urban sanctuary policies and practices have their origin in church-based sanctuary that has sheltered migrants and refugees throughout Europe and the United States from law and immigration enforcement authori- 
ties. In the late 20th Century, municipalities began offering "sanctuary" to refugees and later to illegalized inhabitants (Lippert \& Rehaag, 2013; Ridgley, 2013). Today, sanctuary cities are transforming urban society in various ways: not only are municipal governments defying exclusionary national immigration policies and citizenship laws, but urban sanctuary communities are changing the discourse of migration and belonging and are reimagining the city as an inclusive space. In this way, sanctuary cities are reframing the meaning of belonging and membership at the urban, rather than the national, scale.

Sanctuary city and cities of sanctuary are commonalbeit contested (Bagelman, 2016; Caminero-Santangelo, 2013; Lippert, 2005) - terms in Canada, the USA, and the UK (Bauder, 2017). In other countries, similar municipal policies and practices are typically not labelled "sanctuary." In this article, we examine local policies and practices to accommodate illegalized migrants and refugees in national contexts outside of Canada, the USA, and the UK. We are interested, in particular, if there are common local responses to the problem of exclusion, illegalization, and disenfranchisement caused by national policies. We realize that nation-states have different migration laws and policies, frame their relations to municipal governments in distinct ways, find themselves in various demographic, political, and economic situations, and are situated in unique historical and geopolitical circumstances (Mayer, 2017; Spencer, 2017). Nevertheless, illegalization is a common structural problem across territorial nation states in which political membership is defined by national residency and citizenship rules.

Research on urban sanctuary across national contexts is important because it highlights possible synergies between local responses in countries with different political systems and traditions. Urban sanctuary policies and practices can be seen as part of a "new municipalism" that has been adopted by cities in different parts the world to assert control over their own affairs in light of national and regional austerity, privatization, carbon-consumption, unfair migration, and other repressive policies (Cassia, 2018; Russel \& Reyes, 2017). Recognizing the synergies between urban sanctuary policies and practises in different parts of the world is vital to facilitate international exchange of municipal policy options and ideas, and encourage international networking among urban policy makers, activists, organizers, and other stake holders. In this way, this article aligns with a recent call made from a predominantly US perspective to think of sanctuary in global terms (Carney, Gomez, Mitchell, \& Vannini, 2017).

\section{Background}

Newcomers tend to gravitate to cities to take advantage of perceived labour market opportunities, the existence of a settlement and integration infrastructure, proximity to co-ethnic communities, and, in the case of illegalized migrants, the opportunity to live in relative anonymity. In light of a trend in many immigrant-receiving countries towards downloading integration services from national to lower levels of government and civil society (Shields, Drolet, \& Valenzuela, 2016), cities and regions have become "laboratories" for integration and the development of innovative migration policy (Schmidtke, 2014). Sanctuary cities are such an innovation in response to restrictive national migration policies and increasing responsibilities assumed by municipal governments and civic society.

Sanctuary cities do not offer absolute protection from federal immigration authorities in the sense that they nullify federal law. Rather, illegalized migrants remain subject to detection, and possible detention and deportation even in sanctuary cities (American Immigration Council, 2015; Tramonte, 2011). Although sanctuary cities are unable to offer complete protection, they commit to including all inhabitants-independent of federal status - in the local community and improving the lives of those without full national status.

Sanctuary-city policies and practices are highly context particular (Strunk \& Leitner, 2013). In the United States, sanctuary cities date back to the 1980s, when the City of San Francisco refused to cooperate with federal authorities and chose to protect refugees from Central America (Mancina, 2013). In subsequent decades, sanctuary cities focused increasingly on illegalized migrants settling more-or-less permanently in a municipality rather than on refugees requiring temporary protection (Ridgley, 2008, 2013). Among the concrete sanctuary measures in US cities are municipal laws and policies that prohibit municipal service providers, including the local police forces, school boards, and health and recreational offices, to cooperate with federal migration enforcement authorities and to collect information on residents' federal status and/or exchange this information with federal authorities (Don't Ask, Don't Tell). To establish whether a person is a resident of the municipality, some sanctuary cities accept utility bills, municipal ID cards, or matrículas consulares in lieu of federal or state documents (Varsanyi, 2010).

Sanctuary cities also exist in Canada, where Toronto adopted Don't-Ask-Don't-Tell policies in 2004, which was followed by a vote in City Council in 2013. Although the local police and front-line municipal service workers have not always implemented sanctuary policies properly (Hudson, Atak, Manocchi, \& Hannan, 2017), these policies send an important symbolic message that all inhabitants are included in the local community (McDonald, 2012).

In the UK "cities of sanctuary" do not focus so much on policing or non-cooperation with national authorities as on the symbolic inclusion of refugees seeking protection. These cities change the imagination of the city as a place of welcome and in this way shape the manner in which inhabitants interact with each other (Darling, 2010; Darling \& Squire, 2013; Squire \& Bagelman, 2012).

In the context of the USA, Canada, and the UK, four aspects define a sanctuary city (Bauder, 2017): (1) le- 
gality, i.e. an official commitment by the municipal legislative body to support sanctuary policies and practices; (2) discourse, i.e. challenging exclusionary narratives that portray migrants and refugees as criminal and undeserving; (3) identity, i.e. the formation of collective identities expressing unified membership in an urban community; and (4) scale, i.e. rejecting national migration and refugee laws, and articulating policies and practices of belonging at the municipal scale. These four aspects combine in various ways in different contexts. Nevertheless, their presence can be used as a comprehensive definition of what constitutes a sanctuary city. In the below analysis we apply this definition to national contexts where the term "sanctuary city" is not typically used.

\section{Research Question and Case Studies}

Various aspects of sanctuary-city policies and practices exist around the globe, although the term "sanctuary city" is rarely applied outside of Canada, the UK, and the USA. We therefore ask the following research question: do sanctuary cities de-facto exist outside Canada, the UK, and the USA, although they are not called by this name? To answer this question affirmatively would require all four sanctuary-aspects to be present in a city.

To address this research question, we examined nonEnglish speaking national contexts. Our choice of Spain, Chile, and Germany was guided by the combination of scholarly expertise in Europe and Latin America, and our proficiency in German and Spanish. The three countries have recently received large numbers of migrants and refugees, many lacking or possessing only precarious national status.

In Spain, municipalities are responsible for collecting demographic information irrespectively of migration status. By comparing the number of residence permits issued by the Spanish Home Office (Secretaría General de Inmigración y Emigración) with the number of third-country nationals who registered with the Municipal Population Register (Padrón Municipal), it was estimated that approximately 600,000 undocumented people resided in Spain in 2012 (PICUM, 2013). In the Spanish context, "refuge city" is sometimes used to describe municipal initiatives to accommodate illegalized migrants.

An estimated 150,000 illegalized people resided in Chile in 2017 (Kozak, 2017). Most migrants enter Chile as tourists and subsequently apply for residency or other form of regularization within the country (Pedemonte \& Dittborn, 2016). The term "cities of solidarity" (ciudades solidarias) is used throughout Latin America to describe an initiative under the Mexico Plan of Action, signed in 2004, on the 20th anniversary of the Cartagena Declaration, by 20 Latin-American countries. This initiative aims to promote the integration of refugees in the region by recognizing municipalities' roles in identifying migrants' needs, evaluate the conditions of integration, and establish plans of action (Thayer Correa, Correa, \& Novoa, 2014; Varoli, 2010).
An estimated 180,000 to 520,000 "irregular" migrants lived in Germany in 2014 (Vogel, 2015). This estimate includes people living in Germany who are unknown to German authorities, people with false identity papers, and people hiding from authorities. Other estimates suggest that the number of illegalized migrants in Germany is as high as 1 million (Lebuhn, 2016). In addition, there are "tolerated" (geduldete) migrants with permission to stay but without long-term perspective to remain in Germany. In light of the massive arrival of migrants and refugees since 2015-many of whom have neither received status nor returned to their origin countries - these numbers are expected to have grown (PICUM, 2015). In the German context, scholars and activists have used the term "sanctuary city" among other terms. However, a barrier to the implementation of corresponding policies at the municipal scale is federal legislation that requires municipalities to register and report all residents (e.g., Heuser, 2017; Scherr \& Hofmann, 2016).

We surveyed the academic and gray literature related to these three countries as well as internet-based sources, such as municipal websites, to examine local policies and practices towards illegalized migrants and refugees. We read and analyzed these sources in their original languages. Any quotes presented below that were drawn from non-English sources were translated by us. Once we obtained an overview of national, regional, and municipal legal and policy contexts, we explored if particular cities could be considered "sanctuary cities" based on the four aspects of legality, discourse, identity, and scale. For this purpose, we examined multiple cities in each national context.

In presenting our findings, we focus on one particular city in each country. Initially, our survey did not focus on any particular city. However, the survey revealed that urban sanctuary policies and practices are more prominent in some cities than others. The cities we finally selected are thus not the only cities in their countries that have adopted policies and practices that represent "sanctuary" aspects. For example, in the case of Germany, the city councils of Munich and Cologne commissioned studies to improve the living conditions of illegalized inhabitants; a number of cities, such as Berlin and Hamburg, have experimented with or are considering anonymous medical insurance (Krankenschein) to provide illegalized inhabitants with access to medical services; in many other German cities, civil society institutions have formed local networks to support illegalized migrants and refugees (Heuser, 2017; Migazin, 2014). The cities we included in the below discussion were selected because they illustrate how the aspects of urban sanctuary have been addressed in various national contexts. The scope of this article does not permit us to elaborate on more than one city in each of the countries. 


\section{Results}

\subsection{Spain}

\subsubsection{National Context}

The multi-level governance of Spain provides municipalities with decentralized self-rule (Keating, 2000). The Spanish constitution (Article 148.1.22) recognizes the municipal autonomy in matters of police presence and requires the municipal and local police (policía municipal/local or guardia urbana) to report to local townhalls in municipalities with a population over 5,000 inhabitants (Granda, 2014). Since municipal police forces operate largely independently from the national police (policía nacional) and the civil guard (guardia civil), they can be included in sanctuary-city policies.

Illegalized residents acquire access to municipal services through the Municipal Population Register, which requires all residents by law to register regardless of their immigration status. This register provides proof of residency in the municipality but is not an identification document confirming legal residence in Spain (Instituto Nacional de Estadística, 2016). Given the autonomy of local governments granted by the Spanish constitution, the municipal registration process (enpadronamiento) varies considerably by municipality. Some migrants may not register because they fear that national authorities could access municipal databases, or they lack knowledge of or are misinformed about the requirements, benefits, or process of completing the registration (Arango \& Jachimowicz, 2005). However, when successfully completed, the registry has been instrumental in granting illegalized migrants access to social services, compulsory education for minors, and health identity cards (tarjeta sanitaria) required for medical appointments (Cimas et al., 2016; Escandell \& Tapias, 2010).

Access to health services illustrates the interplay between various levels of government. Prior to 2012, Spanish law provided inhabitants registered with municipalities similar access to health care, irrespective of citizenship or legal status (Cimas et al., 2016). A 2012 reform linked access to health care to citizenship or registry with the Social Security department (Seguro Social). Spain's autonomous regions responded by introducing various pieces of legislation, enabling municipalities to provide at least some degree of health care to illegalized migrants (Smith \& LeVoy, 2017).

\subsubsection{Barcelona}

Barcelona exemplifies how the sanctuary-city concept applies in Spain. Barcelona is located in Spain's Catalonia region and has a population of approximately 1.7 million. The city has advocated on the international stage for illegalized migrants and refugees, stressing the role cities play in this respect (Ayuntamiento de Barcelona, 2014). It has also undertaken concrete steps to promote the rights of all city inhabitants, including illegalized migrants and refugees (Gebhardt, 2016; Smith \& LeVoy, 2017). In particular, it has extended access to all municipal services through the municipal register. Barcelona's "refuge city" initiative (Ayuntamiento de Barcelona, Redacció, 2017) clearly addresses all four aspects of a sanctuary city:

1. Legality: In September 2015, the municipal government launched the "Barcelona, Refuge City" plan. On October 2, 2015, City Council further strengthened its commitment to sanctuary policies by officially declaring Barcelona a "Refuge City" (Ayuntamiento de Barcelona, Secretaría General, 2015);

2. Discourse: In 2010, City Council launched the AntiRumour Strategy (Estratègia BCN Antirumores), which aims to dispel rumors, stereotypes, and myths about the "other" through organizing a variety of awareness-raising campaigns. Some of the main anti-rumor campaigns include: "they don't pay taxes," "collapse of the health care system," "they get all the social benefits," "they take our jobs," and "they are uncivil" (Ayuntamiento de Barcelona, BCN Acción Intercultural, 2017). Moreover, under Barcelona's Refuge City Plan, City Council has advocated for "economic migrants" to obtain access to the system of international protection set up for refugees, "as refugees and migrants alike have left their country of origin or residence in search of safety" (Ayuntamiento de Barcelona, 2017a). These activities challenge the exclusionary discourse around economic migrants and highlight the need for equal protection;

3. Identity: The City of Barcelona and its residents have been proactive in imagining the city as a space of co-belonging. In February 2017, tens of thousands of demonstrators filled the streets of Barcelona following a call from mayor Ada Colau to challenge the Spanish government's failure to meet its pledge to accept more refugees (Agence France-Presse, 2017). The group Casa Nostra, Casa Vostra (Our Home Is Your Home), which organized the protest, has long advocated for the protection and the right to a dignified life for refugees and illegalized migrants (Casa Nostra, Casa Vostra, 2017);

4. Scale: Barcelona has created institutions at the local scale, mitigating exclusionary national migration and refugee policies. The city's Care Service Centre for Immigrants, Emigrants, and Refugees (Servicio de Atención a Inmigrantes, Emigrantes y Refugiados)-run jointly by the City, Barcelona Lawyers' Association, Red Cross, and various other civic-society organizations-provides free services to all city residents regardless of status. In 2014, the City of Barcelona hosted the first Mayoral Forum on Mobility, Migration, and Development, which resulted in the "Declaration of Barcelona." This declaration stresses the role of cities in receiving migrants, demanding comprehensive leg- 
islation regarding immigration, and calling for decent living conditions (Ayuntamiento de Barcelona, 2014). The Declaration and Barcelona's subsequent Refuge City initiative rejects national approaches towards migration and refugee intake: "towns and cities receive and integrate refugees but in Spain [these town and cities] are not involved in asylum policies, nor do they receive any funding to implement them" (Ayuntamiento de Barcelona, 2017b). By establishing a European network of Cities of Refuge (Red Europea de Ciudades de Refugio), the Barcelona, Refuge City Plan aims to create "an inter-municipal space," which would provide the necessary local services for the arrival and reception of refugees through bilateral agreements among the municipalities in the network (Ayuntamiento de Barcelona, 2017c).

\subsection{Chile}

\subsubsection{National Context}

Immigration law in Chile mostly derives from the 1975 security decree (Decreto Ley 1.094), which intrinsically views migrants as potential subversives and therefore grants excessive discretion to the armed border authority (Pedemonte \& Dittborn, 2016). After dictator Pinochet's fall, Chile welcomed refugees from SouthAmerican, Caribbean, and European countries (Leo, Morand, \& Murillo, 2015). In recent years, however, there have been growing anti-refugee and immigrant sentiments (Teletrece, 2017).

The Constitution of 1980 is still in force. However, the tight administrative, fiscal, and regulatory framework of the central state has been questioned and in 1992 the Organic Law of Municipalities (Ley No 18.695, Orgánica Constitucional de Municipalidades) established municipal autonomy. This legislation progressively transformed municipalities into self-governing entities. In 2014, the appointment of the Presidential Advisory Commission for Decentralisation and Regional Development by Chile's president sought to modernize and strengthen municipal functions and transfer new competencies to the new self-governing regions in the areas of economic, social, infrastructure, and housing development (Organization of American States, 2008; UCLG, 2016).

The Chilean national police (the Carabineros) have jurisdiction over the entire national territory. Chilean municipalities do not possess independent police forces. During the Pinochet regime, the Carabineros became highly militarised and gained considerable autonomy. Since then, police reform has been largely delegated to the Carabineros themselves, which continue to retain substantial autonomy from civilian governance (Bonner, 2013). Preventive identity checks are an autonomous faculty of the Carabineros, regulated in Article 85 of the Code of Criminal Procedure (Código Procesal Penal) (Irarrázabal González, 2015). In 1998, this power was restricted (through Law No. 19.567). However, in 2015 the Citizens Security Commission of the Chamber of Deputies (Comisión de Seguridad Ciudadana de la Cámara de Diputados) approved legislation that reinstated the Carabineros' power to carry out preventive identity checks based on suspicion of committing or attempting to commit a crime or concealing one's identity (Irarrázabal González, 2015; Rivas, 2015). Although these developments obstructed the inclusion of the police in sanctuary-city initiatives, the increased decentralization and growing autonomy of regions and municipalities has resulted in innovative local initiatives granting inhabitants access to education, health care, and other social services independent of national status (Thayer Correa, Correa, \& Novoa, 2014).

\subsubsection{Quilicura}

Quilicura is located in the Santiago metropolitan region and has experienced rapid population growth. In 2012, it had about 204,000 inhabitants. Since 2000, Quilicura has received substantial numbers of Haitian and Palestinian migrants and refugees. Given the language and cultural barriers between the new and established residents, the municipality approached UNHCR for help to develop innovate local programs within the framework of the Mexico Plan of Action (Leo et al., 2015; Thayer Correa et al., 2014). These programs address the four aspects of a sanctuary city, although the preferred local label is "Commune of Reception" (Comuna de Acogida).

1. Legality: In 2014, the municipal government launched the Action Plan for the Reception and Recognition of Migrants and Refugees (Plan de Acogida y Reconocimiento de Migrantes y Refugiados), which offers a sustainable and democratic policy for all inhabitants regardless of their administrative status. These initiatives represent official commitments by the municipal legislative body to support sanctuary policies and practices;

2. Discourse: Quilicura's reception initiative is founded on the promotion of equality: equal rights and duties, and full civil, cultural, and social participation of all inhabitants. The municipal government has articulated corresponding policies within a human rights framework, breaking away from an emphasis on the contributions migrants make to society (Thayer Correa et al., 2014). Furthermore, the municipal government is vocal about its dislike of the term "illegal" when referring to nonstatus residents, and explains that some residents are rather in irregular administrative situations (Lizama, 2013);

3. Identity: Quilicura has organized an annual Migrant Fest, which is centered on the idea that culture and diversity are a source of pride and strength in the community. The festival enables all community members to share experiences and 
culture over food, music, and dance, thus fostering a unified community identity (Municipalidad de Quilicura, 2016);

4. Scale: The Municipal Office for Migrants and Refugees (Oficina Municipal para Migrantes y Refugiados) was created in 2010 to provide orientation, support, and information about education and health services, and employment and training opportunities for migrants and refugees (Leo et al., 2015). Quilicura also cooperated with other municipalities to replicate and expand local programs that include all inhabitants (Thayer Correa et al., 2014). In May 2015, Quilicura, with the assistance of the International Maritime Organization (Organización Marítima Internacional), organized Chile's first migrant consultation. This consultation intended to develop ways to register inhabitants of the municipality in regular and irregular situations, create policies that address access to fundamental services and rights, and encourage other levels of government to recognize the benefits of local actors taking initiative (Municipalidad de Quilicura, 2015).

\subsection{Germany}

\subsubsection{National Context}

With the exception of the city-states of Berlin, Bremen, and Hamburg, German municipalities do not possess independent local police forces that could be included in sanctuary-city policies. Instead, policing authority rests largely with the federal police (Bundespolizei), which are responsible for border security, and the regional police (Landespolizei), which assume many other policing functions that require identity and status checks of individuals. German municipal offices have stringent legal reporting obligation (Übermittlungspflicht) to national authorities. National law requires all residents to register at their local registration office (Einwohnermeldeamt), which assesses the identities of residents and reports foreigners to the municipal foreign office (Ausländeramt), which in turn reports visa and status violations to federal authorities. Municipal registration offices can also request from landlords to provide information about their tenants. Federal law and administrative regulations thus provide a relatively restrictive context for the implementation of sanctuary-city policies (Buckel, 2008; Scherr \& Hofmann, 2016; Schönwälder, Vogel, \& Sciortino, 2004).

Despite the restrictive legal and administrative context, illegalized migrants engage in German public life: they use public transit, join faith-based communities, and participate in organized social clubs (Shinozaki, 2015). Many civic and faith-based institutions offer "safe spaces" (Schutzräume) to illegalized immigrants, where they are treated with respect and dignity, not as anonymous statistics (Just, 2013; Zabel, 2001, p. 93). In many cities, hospitals and organizations like Malteser
Migranten Medizin provide medical services for free or reduced fees to people requiring anonymity (Maltester Migranten Medizin, 2016; Misbach, 2008). Schools are exempt from the requirement to report the status of students to authorities (Kößler, Mohr, Habbe, Peter, \& Fodor, 2013). Germany's civic and institutional context is evidently supportive of accommodating illegalized migrants and refugees.

\subsubsection{Freiburg}

The case of Freiburg illustrates how the sanctuary-city concept may be applicable in Germany. Freiburg is located in the state of Baden-Württemberg and has a population of approximately 220,000 . In recent decades, Freiburg's civil society has undertaken concrete steps to accommodate refugees and illegalized migrants, and has raised the issue of illegalized migrants publically (Buckel, 2008). Although, activists favour the term "solidarity city," they have used the term "sanctuary city," calling "upon municipal politics, local institutions (daycare centres, schools, businesses, chambers, hospitals,...) and civil society, that Freiburg joins the sanctuary-city movement" (Freiburger Forum aktiv gegen Ausgrenzung, 2016). Freiburg meets most aspects to be considered a sanctuary city:

1. Legality: At the time of writing, Freiburg's City Council has not formally acknowledged the local sanctuary-city campaign. The missing aspect "legality," however, is precisely the aim of the current campaign. In 2012, City Council did pass a resolution in support of "tolerated" (gedultete) Roma threatened by deportation. This resolution indicated that "communities have become the point of departure for a successful pan-European integration strategy for the inclusion and equal participation of all in political, social, and cultural respects" (Freiburger Gemeinderat, 2012);

2. Discourse: Local initiatives challenge exclusionary national migration and refugee discourses and status categories. The Freiburger Forum aktiv gegen Ausgrenzung (Freiburger Forum aktiv gegen Ausgrenzung, n.d.) calls on readers to reject politicians who "want to make people believe that deportations are necessary [and who] distinguish between deserving and undeserving refugees." Local campaigns also contest the state-imposed illegality of persons and stress the common humanity of all inhabitants of Freiburg, and public media outlets, such as Radio Dreyeckland (https://rdl.de), challenge narratives that depict migrants and refugees as criminal, undeserving, and predatory. An antimigrant demonstration organized by a right-wing party in the wake of the murder of a 20-year old university student drew only 15-20 attendees but was met by a counter-demonstration of 300 people, in which Anti-Fascists and representatives 
of mainstream political parties marched together (Mauch, 2016);

3. Identity: Expressions of solidary with illegalized migrants are common among activists and civic institutions in Freiburg. These expressions are often complemented by calls for a united urban community that does not distinguish between people based on national status. For example, a prominent support project for illegalized migrants proclaims as its central idea to "live in direct communal solidarity" and demands "cohabitation in the city without discriminating state regulations" (Rasthaus, 2017);

4. Scale: Freiburg possess a highly effective local infrastructure of civic institutions-including $A k$ tion Bleiberecht, the Freiburger Forum aktiv gegen Ausgrenzung, Medinez (medizinische Behandlung für papierlose MigrantInnen), Rasthaus, and the Südbadische Aktionsbündnis gegen Abschiebung (SAGA) - that provides a range of services to local residents without or with precarious national status. The initiative Rasthaus, which is a housing complex centrally-located in Freiburg, serves as a hub for accessing medical services, housing, legal and financial aid, German language courses, and other supports to illegalized migrants. These organizations and projects are closely networked with each other and external support groups. Collectively, they aim to include illegalized migrants in the local community in light of exclusionary national migration and refugee laws and policies.

\section{Conclusion}

Although our empirical research focused on only three countries and three cities, urban-sanctuary initiatives are also advancing in Brazil, Italy, Switzerland, and other countries. Accommodating illegalized migrants and refugees at the local scale is not an isolated but a global phenomenon. However, different terms are used in different countries to describe similar urban policies and practices: the term "sanctuary" is popular in Canada, the US, and the UK. This term has historically had religious connotations and meaning (Caminero-Santangelo, 2013). Today, "sanctuary" cities involve largely secular urban policies and practices. In other countries, preferred terms include "refuge cities," "commune of reception," or "solidarity city." Different terminology can even be used within a single city. In Freiburg, both "sanctuary" and "solidarity" city have been in circulation. In Toronto, the key organization that advocated for the sanctuary city was the Solidary City Network. While it may be tempting to attribute "sanctuary" with a managed topdown approach and "solidarity" to bottom-up activism, a common feature of the urban policies and practices to protect illegalized migrants and refugees is that they blend bottom-up and top-down approaches. In this way, sanctuary-city policies and practices align with the new municipalist movement that can neither be conceptual- ized as strictly top-down nor bottom-up (Russel \& Reyes, 2018). Adding to the complexity, urban policies and practices may not only focus on illegalized inhabitants but also on resettling refugees and on accommodating other vulnerable populations.

The article highlighted the different national contexts in which urban sanctuary policies and practices are implemented. These differences also pose important challenges for transferring urban policies from one national context to another and for applying experiences with aspects of sanctuary to cities located in different countries. For example, in Chile and Germany, where local municipalities do not possess their own police forces, law enforcement usually cannot be included in sanctuary-city policies. In addition, the absence or presence of municipal registries in different countries and the associated reporting obligations to national authorities have profound effect on the types of local policies that can be enacted to accommodate illegalized migrants and refugees. Furthermore, the characteristics of illegalized and precarious migrant and refugee populations vary between countries that are historically, economically, politically, and geopolitically in different situations. Thus, not only policy makers but also civil society institutions and activists operate in very dissimilar environments in different countries. However, this article also highlighted that various municipal, civil society, and activist actors can complement each others' efforts and play various roles to collectively adapt to their unique national context in providing sanctuary to illegalized inhabitants. When municipalities are legally constrained to offer a particular type of service, civil society institutions may be able to step in to provide this service and vice versa.

The language surrounding sanctuary policies and practices is highly politicized and context particular. However, that various terminologies are used internationally and contexts differ between countries should not distract policy makers, activists, and decision makers from realizing the commonalities among urban policies and practices to protect and include illegalized migrants and refugees. It is important to look beyond particular labels and existing national idiosyncrasies to realize how urban municipalities and local civic society are using the scope of their possibilities to enact policies and practices along the four "sanctuary" dimensions to tackle the common structural problem of the illegalization and disenfranchisement of people at the national scale. Building on initiatives, such as the Declaration of Barcelona, the Mexico Plan of Action, and EUROCITIES's Solidarity Cities initiative, this realization can facilitate further information exchanges and networking activities between urban actors, with the ultimate aim to establish a global urban strategy towards including all inhabitants.

\section{Acknowledgments}

We thank Tim Freytag, Annika Mattissek, and their colleagues at the University of Freiburg, and Cristián 
Cornejo, Ulrike Hamann, Lorelle Juffs, Janika Kuge, MarieFrance Russo, Albert Scherr, Inga Schwarz, Holger Wilke, Gökçe Yurdakul, and the anonymous reviewers. Support was provided by the Ontario-Baden-Württemberg Research Exchange Program, the Konrad-Adenauer Research Award, and Ryerson University's Yates School of Graduate Studies. An earlier and condensed version was presented to the International Organization for Migration.

\section{Conflict of Interests}

The authors declare no conflict of interests.

\section{References}

Agence France-Presse. (2017, February 18). Protesters in Barcelona urge Spain to take in more refugees. The Guardian. Retrieved from www.theguardian.com/ world/2017/feb/18/protesters-in-barcelona-urgespain-to-take-in-more-refugees

American Immigration Council. (2015). "Sanctuary cities," trust acts, and community policing explained. American Immigration Council. Retrieved from www. immigrationpolicy.org/just-facts/sanctuary-citiestrust-acts-and-community-policing-explained

Arango, J., \& Jachimowicz, M. (2005). Regularizing immigrants in Spain: A new approach. Migration Information Source. Retrieved from www.migrationpolicy.org /article/regularizing-immigrants-spain-new-approach

Ayuntamiento de Barcelona. (2014). Call of Barcelona. Retrieved from http://www.bcn.cat/novaciutadania/ $\mathrm{pdf} / \mathrm{ca} /$ home/DeclaracioBcn.en.pdf

Ayuntamiento de Barcelona. (2017a). Barcelona, refuge city-FAQs. Barcelona.cat. Retrieved from http://ciutatrefugi.barcelona/en/faqs

Ayuntamiento de Barcelona. (2017b). Barcelona, refuge city-Reception, accommodation and care. Barcelona.cat. Retrieved from http://ciutatrefugi. barcelona/en/reception-accommodation-and-care

Ayuntamiento de Barcelona. (2017c). Barcelona, refuge city-The plan. Barcelona.cat. Retrieved from http://ciutatrefugi.barcelona/en/plan

Ayuntamiento de Barcelona, BCN Acción Intercultural. (2017). Estratègia BCN antirumores. Barcelona.cat. Retrieved from http://ajuntament.barcelona.cat/ bcnacciointercultural/es/antirumores-que-hacemos

Ayuntamiento de Barcelona, Redacció. (2017). A municipal front by refuge cities. Barcelona.cat. Retrieved from http://ciutatrefugi.barcelona/en/noticia/a-mu nicipal-front-by-refuge-cities_487542

Ayuntamiento de Barcelona, Secretaría General. (2015). Acuerdos adoptados por el Plenario del Consejo Municipal en la sesión ordinaria de 2 de octubre de 2015. Retrieved from http://ajuntament.barcelona. cat/sites/default/files/acords_021015_es_0.pdf

Bagelman, J. (2016). Sanctuary city: A suspended state. New York: Palgrave Macmillan.
Bauder, H. (2014). Why we should use the term 'illegalized' refugee or immigrant. International Journal of Refugee Law, 26(3), 327-332.

Bauder, H. (2017). Sanctuary cities: Policies and practices in international perspective. International Migration, 55(2), 174-182.

Bonner, M. D. (2013). The politics of police image in Chile. Journal of Latin American Studies, 45(4), 669-694.

Buckel, S. (2008). Zwischen Repression und Integration: Wie gehen Kommunen mit dem Problem der Illegalität um? In Leben in der Illegalität: Ein Dossier (pp. 35-39). Heinrich-Böll Stiftung.

Caminero-Santangelo, M. (2013). The voice of the voiceless: Religious rhetoric, undocumented immigrants, and the New Sanctuary Movement in the United States. In R. K. Lippert \& S. Rehaag (Eds.), Sanctuary practices in international perspectives: Migration, citizenship and social movements (pp. 92-105). Abingdon: Routledge.

Carney, M. A., Gomez, R., Mitchell, K., \& Vannini, S. (2017). Sanctuary planet: A global sanctuary movement for the time of Trump. Society \& Space. Retrieved from http://societyandspace.org/2017/05/ 16/sanctuary-planet-a-global-sanctuary-movementfor-the-time-of-trump

Casa Nostra, Casa Vostra. (2017). Quiénes somos. Retrieved from www.casanostracasavostra.cat/es/ quienes-somos/organizacion

Cassia, G. (2018). From citizen platform to fearless cities: Europe's new municipalism. Krytyka Politczna \& European Alernatives. Retreived from http://political critique.org/world/2017/from-citizen-platforms-tofearless-cities-europes-new-municipalism

Cimas, M., Gullon, P., Aguilera, E., Meyer, S., Freire, J. M., \& Perez-Gomez, B. (2016). Healthcare coverage for undocumented migrants in Spain: Regional differences after Royal Decree Law 16/2012. Health Policy, 120(4), 384-395.

Darling, J. (2010). A city of sanctuary: The relational re-imagining of Sheffield's asylum politics. Transactions of the Institute of British Geographers, NS 35, 125-140.

Darling, J., \& Squire, V. (2013). Everyday enactments of sanctuary: The UK City of Sanctuary movement. In R. K. Lippert \& S. Rehaag (Eds.), Sanctuary practices in international perspectives: Migration, citizenship and social movements (pp. 191-204). Abingdon: Routledge.

Escandell, X., \& Tapias, M. (2010). Transnational lives, travelling emotions and idioms of distress among Bolivian migrants in Spain. Journal of Ethnic and Migration Studies, 36(3), 407-423.

Freiburger Forum aktiv gegen Ausgrenzung. (2016). Freiburg-Eine Zufluchts-Stadt! Freiburger-forum. net. Retrieved from www.freiburger-forum.net/ 2016/10/freiburg-eine-zufluchts-stadt-die-alle-ihrebuergerinnen-schuetzt

Freiburger Forum aktiv gegen Ausgrenzung. (n.d.). Aufruf 
an alle, die sich für Flüchtlinge engagieren. Pamphlet.

Freiburger Gemeinderat. (2012). Perspektiven für die Roma in Europa-Eine Zukunft für die Roma in Freiburg. Freiburger-forum.net. Retrieved from www. freiburger-forum.net/2012/11/resolution-zur-sitzung -des-freiburger-gemeinderates-am-16-oktober-2012

Gebhardt, D. (2016). Re-thinking urban citizenship for immigrants from a policy perspective. Citizenship Studies, 20, 846-866.

Granda, A. (2014). Un análisis de la seguridad pública en españa: Hacia un nuevo modelo más eficaz (Doctoral dissertation). Retrieved from https://riunet.upv.es/ handle/10251/45690

Heuser, H. (2017). Sanctuary cities in Deutschland: Widerstand gegen die Abschiebepolitik der Bundesregierung. Verfassungsblog. Retrieved from http://verfassungsblog.de

Hudson, G., Atak, I., Manocchi, M., \& Hannan, C. A. (2017). (No) Access T.O.: A pilot study on sanctuary city policy in Toronto, Canada. RCIS Working Paper 2017/1. Retrieved from www.ryerson.ca/rcis/ publications/rcisworkingpapers

Instituto Nacional de Estadística. (2016). Cifras oficiales de población de los municipios españoles: Revisión del Padrón Municipal. Retrieved from www. ine.es/dyngs/INEbase/en/operacion.htm?c=Estadisti ca_C\&cid $=1254736177011 \&$ menu=resultados\&idp= 1254734710990

Irarrázabal González, P. (2015). Igualdad en las calles en Chile: El caso del control de identidad. Política Criminal, 10(19), 234-265.

Just, W. D. (2013). The rise and features of church asylum in Germany: "I will take refuge in the shadow of thy wings until the storms are past." In R. K. Lippert \& S. Rehaag (Eds.), Sanctuary practices in international perspectives: Migration, citizenship and social movements (pp. 135-147). Abingdon: Routledge.

Keating, M. (2000). The minority nations of Spain and European integration: A new framework for autonomy? Journal of Spanish Cultural Studies, 1(1), 29-42.

Kößler, M., Mohr, T., Habbe, H., Peter, E., \& Fodor, R. (2013). Aufenthaltsrechtliche Illegalität-Beratungshandbuch 2013. Freiburg: Deutscher Caritasverband \& Deutsches Rotes Kreuz.

Kozak, P. (2017, June 29). Caribbean migrants risk danger and discrimination for a new life in Chile. The Guardian. Retrieved from www.theguardian. com/world/2017/jun/29/caribbean-migrants-chiledesert-minefield

Lebuhn, H. (2016). Illegalisierung. In B. Belina, M. Naumann, \& A. Strüver (Eds.), Handbuch kritische Stadtgeographie (pp. 228-233). Westfälisches Dampfboot.

Leo, C. C., Morand, M., \& Murillo, J. C. (2015). Building communities of practice for urban refugeesAmericas regional workshop report. United Nations High Commissioner for Refugees. Retrieved from www.unhcr.org/5617bb709.pdf
Lippert, R. K. (2005). Sanctuary, sovereignty, sacrifice: Canadian sanctuary incidents, power and law. Vancouver: UBC Press.

Lippert, R. K., \& Rehaag, S. (2013). Introduction: Sanctuary across countries, institutions, and disciplines. In R. K. Lippert \& S. Rehaag (Eds.), Sanctuary practices in international perspectives: Migration, citizenship and social movements (pp. 1-12). Abingdon: Routledge.

Lizama, J. (2013). Beneficios para niños y mujeres migrantes en Quilicura. Revista Sur. Retrieved from www.revistasur.cl/revistasur.cl/2013/02/beneficiospara-ninos-y-mujeres-migrantes-en-quilicura

Maltester Migranten Medizin. (2016). Retrieved from www.malteser-migranten-medizin.de/startseite.html

Mancina, P. (2013). The birth of a sanctuary-city: a history of governmental sanctuary in San Francisco. In R. K. Lippert \& S. Rehaag (Eds.), Sanctuary practices in international perspectives: Migration, citizenship and social movements (pp. 205-218). Abingdon: Routledge.

Mauch, U. (2016, December 4). 3000 Menschen demonstrieren in Freiburg gegen AfD-Kundgebung mit 20 Teilnehmern. Badische Zeitung. Retrieved from www.badische-zeitung.de/freiburg/300-menschendemonstrieren-in-freiburg-gegen-afd-kundgebungmit-20-teilnehmern-130643198.html

Mayer, M. (2017). Cities as cites of refuge and resistance. European Urban and Regional Studies.

McDonald, J. (2012). Building a sanctuary city: Municipal migrant rights in the city of Toronto. In P. Nyers \& K. Rygiel (Eds.), Citizenship, migrant activism and the politics of movement (pp. 129-145). London: Routledge.

Migazin. (2014, March 12). Kommunaler Umgang mit Menschen ohne Papiere. Retrieved from: http:// www.migazin.de/2014/03/12/kommunaler-umgangmenschen-papiere

Misbach, E. (2008). Gesundheitsversorgung für Menschen in der Illegalität. In Leben in der Illegalität: Ein Dossier (pp. 40-44). Heinrich-Böll Stiftung.

Montpetit, J. (2017, February 21). Sanctuary city movement grows in Canada, but could bring tension with policy, immigration officials. CBCNews. Retrieved from www.cbc.ca/news/canada/montreal/ sanctuary-cities-montreal-canada-toronto-vancouver $-1.3991321$

Municipalidad de Quilicura. (2015, May 19). Consulta Migrante. Retrieved from http://quilicura.cl/index. $\mathrm{php} /$ noticias/36-noticias-generales/1302-consultamigrante.html

Municipalidad de Quilicura. (2016, December 12). Migrafest 2016: Vecinos Disfrutan de una gran fiesta intercultural. Retrieved from www.quilicura.cl/index. php/noticias/36-noticias-generales/1557-migrafest2016-vecinos-disfrutaron-de-una-gran-fiesta-intercul tural.html

Organization of American States. (2008). General politi- 
cal structure of Chile: Form of government. Retrieved from www.oas.org/juridico/mla/en/chl/en_chl-intdes-ord.pdf

Pedemonte, N. R., \& Dittborn, C. S. (2016). La migración en Chile: breve reporte y caracterización. Observatorio Iberoamericano sobre Movilidad Humana, Migraciones y Desarrollo. Retrieved from www.extranjeria. gob.cl/media/2016/08/informe_julio_agosto_2016. pdf

PICUM. (2013). PICUM submission to the UN Committee on the Protection of the Rights of All Migrant Workers and Members of their Families. Retrieved from http://www.ohchr.org/Documents/HRBodies/CMW/ Discussions/2013/DGDMigrationData_PICUM_2013. pdf

PICUM. (2015). Letter from PICUM's Director on International Migrant's Day-Changing the narrative. Brussels.

Rasthaus. (2017). Rasthaus-Idee. Retrieved from http:// rasthaus-freiburg.org/userfiles/downloads/tafel_ras thaus_2_idee.pdf

Ridgley, J. (2008). Cities of refuge: Immigration enforcement, police, and the insurgent genealogies of citizenship in U.S. Sanctuary Cities, Urban Geography, 29(1), 53-77.

Ridgley, J. (2013). The city as a sanctuary in the United States. In R. K. Lippert \& S. Rehaag (Eds.), Sanctuary practices in international perspectives: Migration, citizenship and social movements (pp. 219-231). Abingdon: Routledge.

Rivas, F. (2015). Control de identidad preventivo: ¿el regreso de la detención por sospecha? BioBio Chile. Retrieved from www.biobiochile.cl/noticias/2015/ 06/09/control-de-identidad-preventivo-el-regreso-de -la-detencion-por-sospecha.shtml

Robbins, L. (2017, January 25). 'Sanctuary city' mayors vow to defy Trump's immigration order. The New York Times. Retrieved from www.nytimes.com/2017/01/ 25/nyregion/outraged-mayors-vow-to-defy-trumpsimmigration-order.html

Russel, B., \& Reyes, O. (2017). Fearless cities: The new urban movements. Red Peper. Retrieved from www. redpepper.org.uk/fearless-cities-the-new-urban-move ments

Scherr, A., \& Hofmann, R. (2016). Sanctuary cities: Eine Perspektive für deutsche Kommunalpolitik? Kritische Justiz, 1, 1-13.

Schmidtke, O. (2014). Beyond national models: Governing migration and integration at the regional and local levels in Canada and Germany. Comparative Migration Studies, 2(1), 77-99. Retrieved from https:// www.imiscoe.org/journal-cms-2/2014-1/21-schmidt ke-oliver-beyond-national-models-governing-migra tion-and-integration-at-the-regional-and-local-levels -in-canada-and-germany-pp-77-99/file

Schönwälder, K., Vogel, D., \& Sciortino, G. (2004). Migration und Illegalität in Deutschland. Berlin: Wissenschaftszentrum Berlin für Sozialforschung.

Shields, J., Drolet, J., \& Valenzuela, K. (2016). Immi- grant settlement and integration services and the role of nonprofit service providers: A crossnational perspective on trends, issues and evidence. RCIS Working Paper 2016/1. Retrieved from https:// www.ryerson.ca/rcis/publications/rcisworkingpapers

Shinozaki, K. (2015). Migrant citizenship from below: Family, domestic work, and social activism in irregular migration. New York: Palgrave Macmillan.

Smith, C. A., \& LeVoy, M. (2017). Cities of rights: Ensuring health care for undocumented residents. PICUM. Retrieved from http://picum.org/picum.org/ uploads/publication/CityOfRights_FINAL_WEB_EN. pdf

Spencer, S. (2017). Multi-level governance of an intractable policy problem: Migrants with irregular status in Europe. Journal of Ethnic and Migration Studies.

Squire, V., \& Bagelman, J. (2012). Taking not waiting: Space, temporality and politics in the City of Sanctuary movement. In P. Nyers \& K. Rygiel (Eds.), Citizenship, migrant activism and the politics of movement (pp. 146-164). London: Routledge.

Strunk, C., \& Leitner, H. (2013). Resisting federal-local immigration enforcement partnerships: Redefining 'secure communities' and public safety. Territory, Politics, Governance, 1(1), 62-85.

Teletrece. (2017, June 29). El crudo análisis del diario inglés The Guardian sobre la situación de los inmigrantes en Chile. Retrieved from http://t13.cl/ 216714

Thayer Correa, L. E., Correa, S., \& Novoa, T. (2014). Plan de acogida y reconocimiento de migrantes y refugiados de la comuna de Quilicura. Municipalidad de Quilicura. Retrieved from http://web.minsal.cl/wpcontent/uploads/2015/09/BP04Plan-acogida-y-reco nocimiento-Quilicura-2014.pdf

Tramonte, L. (2011). Debunking the myth of "sanctuary cities": Community policing policies protect American communities. Immigration Policy Centre. Retrieved from www.immigrationpolicy.org/sites/ default/files/docs/Community_Policing_Policies_Pro tect_American_042611_update.pdf

UCLG. (2016). Chile: Unitary country. Retrieved from www.oecd.org/regional/regional-policy/profile-Chile. pdf

Varoli, F. (2010). Cities of solidarity: Local integration in Latin America. Forced Migration Review, 34, 44-46.

Varsanyi, M. W. (2010). Taking local control: Immigration policy activism in U.S. cities and states. Stanford: Stanford University Press.

Vogel, D. (2015). Update report Germany: Estimated number of irregular foreign residents in Germany (2014). Clandestino: Database on Irregular Migration. Retrieved from www.irregular-migration.net

Zabel, U. (2001). Aus der Beratungsarbeit mit Zuwanderern ohne Aufenthaltsrecht und Duldung im CaritasMigrationsdienst Berlin. In K. J. Bade (Eds.), Integration und Illegalität in Deutschland (pp. 91-99). Osnabrück: IMIS \& Rat für Migration. 


\section{About the Authors}

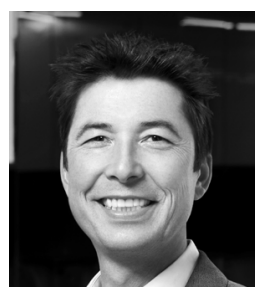

Harald Bauder is a Professor in the Department of the Geography and Environmental Studies and the Director of the Graduate Program in Immigration and Settlement Studies at Ryerson University in Toronto, Canada. He is a member of the Migration Research Leaders Syndicate of the International Organization for Migration, which was formed in preparation for the Global Compact for Migration. His most recent book is titled Migration Borders Freedom (Routledge, 2017).

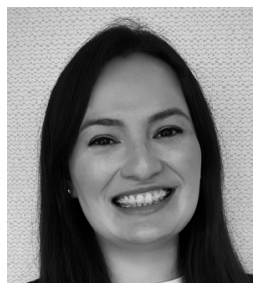

Dayana A. Gonzalez completed her Master's in Immigration and Settlement Studies at Ryerson University and undergraduate studies in Law and Society at York University, Canada. She was the recipient of the Best Master's Research Project award from the Graduate Program in Immigration and Settlement Studies and the Immigration and Settlement Studies Student Leadership Award in 2017. Her research interests include, but are not limited to, the intersection of migration and law, border controls, immigration enforcement, and citizenship. 